\title{
Glade Creek at Oil Lease Grave Site, Gregg County, Texas
}

Timothy K. Perttula

Heritage Research Center, Stephen F. Austin State University

Follow this and additional works at: https://scholarworks.sfasu.edu/ita

Part of the American Material Culture Commons, Archaeological Anthropology Commons, Environmental Studies Commons, Other American Studies Commons, Other Arts and Humanities Commons, Other History of Art, Architecture, and Archaeology Commons, and the United States History Commons

Tell us how this article helped you.

This Article is brought to you for free and open access by the Center for Regional Heritage Research at SFA ScholarWorks. It has been accepted for inclusion in Index of Texas Archaeology: Open Access Gray Literature from the Lone Star State by an authorized editor of SFA ScholarWorks. For more information, please contact cdsscholarworks@sfasu.edu. 


\section{Glade Creek at Oil Lease Grave Site, Gregg County, Texas}

Creative Commons License

(c) (i) (8)

This work is licensed under a Creative Commons Attribution-NonCommercial 4.0 International License 


\title{
Glade Creek at Oil Lease Grave Site, Gregg County, Texas
}

\author{
Timothy K. Perttula
}

\section{INTRODUCTION}

The Glade Creek at Oil Lease Grave site is reported by Buddy C. Jones to have been a large Caddo cemetery that was found and excavated by a Mr. C. W. Bailey sometime before 1954. Jones labeled the site as GC-23 in his site recording system. As far as can be determined from the available notes, the site was located on Glade Creek, a small spring-fed stream that is a tributary to Witcher Creek, in the Little Cypress Creek basin (Patti Haskins, July 2013 personal communication) in the northern part of Gregg County, Texas, in the East Texas Pineywoods.

A single ceramic vessel from the site is in the Buddy Jones collections at the Gregg County Historical Museum in Longview, Texas. The vessel was documented in July 2013.

\section{VESSEL}

SITE NAME OR SITE NUMBER: Glade Creek at Oil Lease Grave

VESSEL NO.: 2003.08.1955

NON-PLASTICS AND PASTE: grog

VESSEL FORM: Carinated bowl

RIM AND LIP FORM: Direct rim and a rounded, exterior folded lip

CORE COLOR: $\mathrm{F}$ (fired in a reducing environment and cooled in the open air)

INTERIOR SURFACE COLOR: yellowish-brown

EXTERIOR SURFACE COLOR: yellowish-brown

WALL THICKNESS (RIM, BODY, AND BASE IN MM): rim, $7.1 \mathrm{~mm}$; body, $7.5 \mathrm{~mm}$

INTERIOR SURFACE TREATMENT: smoothed

EXTERIOR SURFACE TREATMENT: burnished

HEIGHT (IN CM): 11.9

ORIFICE DIAMETER (IN CM): 28.0

DIAMETER AT BOTTOM OF RIM OR NECK (IN CM): 11.2 


\section{BASE DIAMETER (IN CM) AND SHAPE OF BASE: N/A}

\section{ESTIMATED VOLUME (IN LITERS): 1.9}

DECORATION (INCLUDING MOTIF AND ELEMENTS WHEN APPARENT): The rim panel has a simple engraved scroll motif repeated four times around the vessel. Instead of upper and lower scroll fill zones, there are upper and lower rows of excised pendant triangles (as is more commonly seen on Ripley Engraved, var. McKinney). The engraved scrolls are divided from each other by brackets comprised of single vertical engraved lines connected with larger upper and lower excised triangles (Figure 1).

PIGMENT USE AND LOCATION ON VESSEL: none

TYPE AND VARIETY [IF KNOWN]: Ripley Engraved, cf. var. Gandy

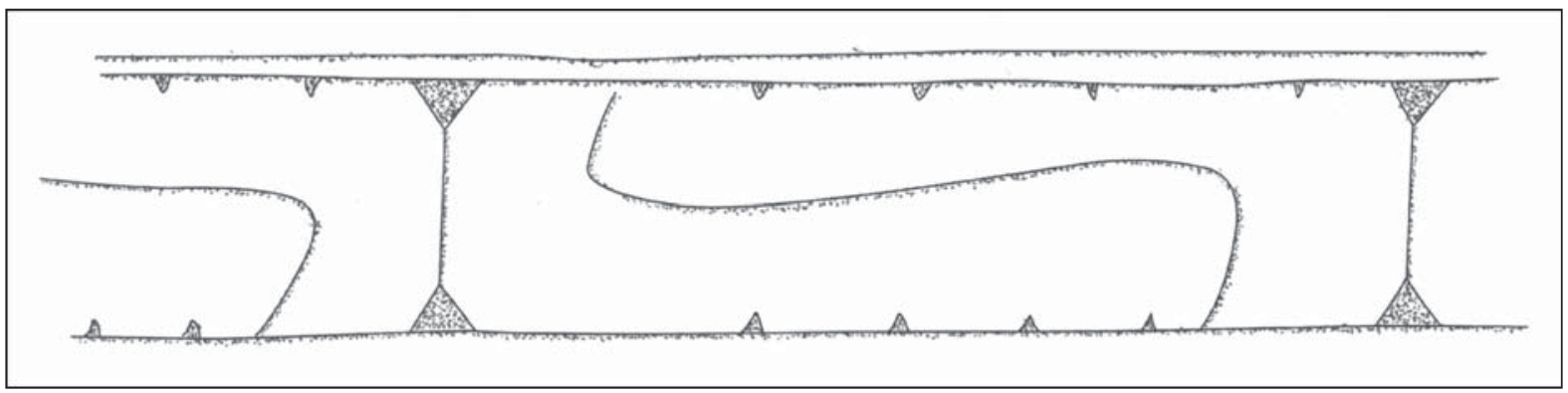

Figure 1. Drawing of engraved motif from the Ripley Engraved, cf. var. Gandy vessel from GC-23 on Glade Creek. Drawing by Lance Trask.

\section{CONCLUSIONS}

The documentation of a single Ripley Engraved, cf. var. Gandy carinated bowl from the Glade Creek at Oil Lease Grave site suggests that the Caddo cemetery at this site is culturally affiliated with the Titus phase. This phase is a Late Caddo (ca. A.D. 1450-1680) cultural complex marked by many dispersed settlements, large and small cemeteries, and mound centers in the Sabine and Big Cypress Creek basins in East Texas (Perttula 2012).

\section{REFERENCES CITED}

Perttula, T. K.

2012 The Character of Fifteenth- to Seventeenth-Century Caddo Communities in the Big Cypress Creek Basin of Northeast Texas. In The Archaeology of the Caddo, edited by T. K. Perttula and C. P. Walker, pp. 363-410. University of Nebraska Press, Lincoln. 